\title{
Acetic Acid and n-Butyric Acid as Causal Agents of Fungicidal Activity of Glucose-amended Flooded Soil
}

\author{
Hiroshi OKazAKI* and Kazuo Nose*
}

\begin{abstract}
Volatile fungicidal substances, which affect the survival of Fusarium oxysporum f.sp. raphani in soil flooded with $3 \%$ glucose solution in vitro, were analysed by using a cryogenic trap, by bioassay, gas chromatography and gas chromatography-mass spectrometry. The antifungal volatile substances collected consisted of two components : acetic acid and n-butyric acid. Their concentrations in the centrifuged supernatant of the soil were 3,407 and 2,944 $\mathrm{ppm}$, respectively, when the fungicidal activity in the soil reached maximum values on the 6th day after flooding. The concentrations were high enough to kill the chlamydospores of the fungus. Other volatile substances including hydrogen sulfide were not related to the fungicidal activity of the soil. These results suggest that the fungicidal activity of glucoseamended flooded soil was associated with the production of acetic acid and n-butyric acid in the soil.
\end{abstract}

(Received October 29, 1985)

Key words : soil, glucose-amendment, Fusarium, acetic acid, n-butyric acid, fungicidal activity.

\section{Introduction}

Flooding of soil is one of the cultural methods for controlling soil-borne diseases caused by Fusarium spp.. Its effectiveness is enhanced by amendment with several organic materials ${ }^{18,26)}$. The beneficial effect of organic amendments has been attributed to either the increase in the number of competitive microorganisms ${ }^{19)}$ or the production of a volatile inhibitor ${ }^{12)}$. In the previous paper, it was suggested that the death of Fusarium oxysporum f. sp. raphani in glucose-amended flooded soil was due to the presence of volatile fungicidal substance(s) evolved from the soil15). As an extension of the previous work, in the present paper the identification of the volatile substances responsible for the death of $F$. oxysporum f. sp. raphani in the soil flooded with a glucose solution is reported. A preliminary account of this work has already been published ${ }^{16)}$.

\section{Materials and Methods}

Fungus. An isolate of Fusarium oxysporum f. sp. raphani was used. Hereafter this fungus will be referred to as $F$. oxysporum.

Soil. Soil was collected in the cultivated upland field of the National Institute of

\footnotetext{
* National Institute of Agro-Environmental Sciences, Yatabe, Tsukuba, Ibaraki 305, Japan 農業
} 檟境技術研究所 
Agro-Environmental Sciences, Yatabe, Ibaraki Prefecture. The soil was passed through a 2-mm sieve and stored under field moisture conditions until use.

Soil treatment. Ten $\mathrm{g}$ of soil was put in 200-ml Erlenmyer flasks, flooded with $10 \mathrm{ml}$ of $3 \%$ glucose solution and incubated at $28 \mathrm{C}$. Soil flooded without glucose was also incubated as a control. The soil suspension was centrifuged at $1,000 \times g$ for 5 min to obtain the supernatant.

Collection of volatile substances. Volatile substances in the soil were collected by using the apparatus illustrated in Fig. 1. A silicone rubber stopper with inlet and outlet tubes was attached to the 200-ml Erlenmyer flask containing the soil. The flask

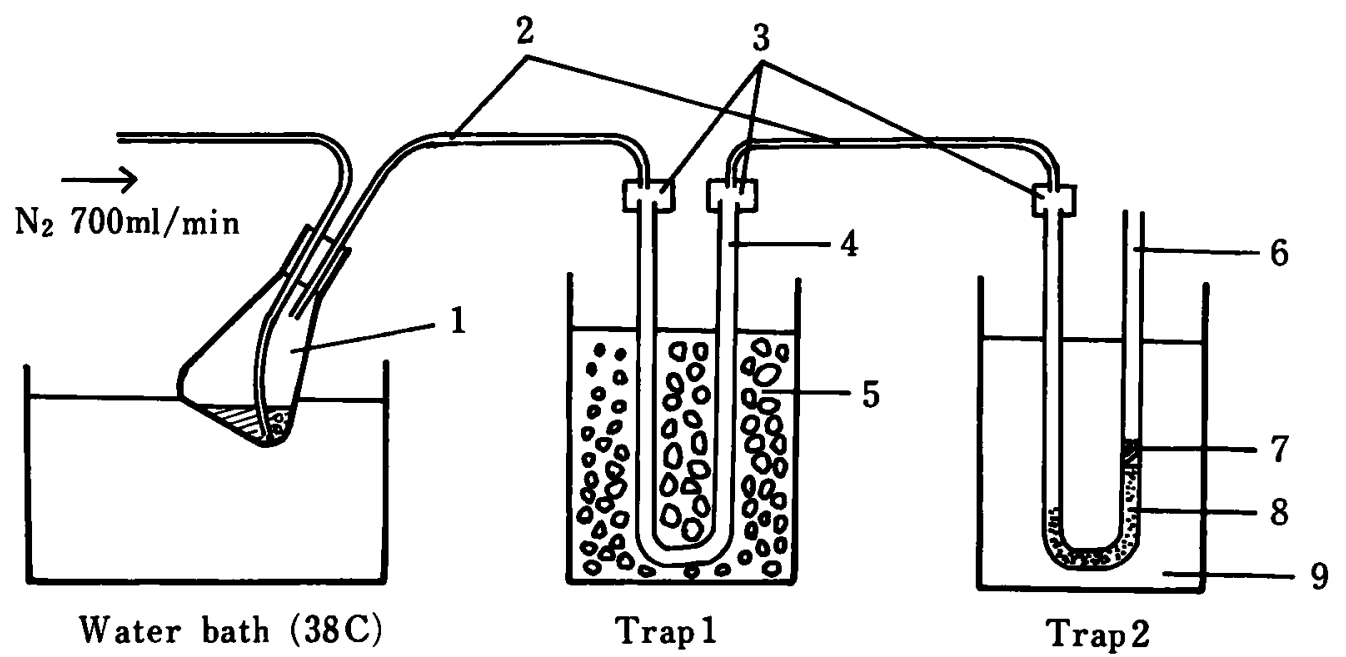

Fig. 1. Apparatus for cryogenic collection of volatile substances. The numbers correspond to the following items: 1: a 200-ml Erlenmyer flask containing $10 \mathrm{~g}$ of soil sample, 2: Teflon tube $(2 \mathrm{~mm}$ i.d.), 3: Teflon tube connection, 4: U-shaped Teflon tube $(4 \mathrm{~mm}$ i. d.), 5: cooling bath with freezing mixture of ice and salt $(-20 \mathrm{C}), 6$ : U-shaped Teflon tube with $500 \mathrm{mg}$ of Flusin T, 7: glass-wool plug, 8: Flusin T, 9: ethanol cooling bath $(-20-$ $-60 \mathrm{C})$.

was placed in a water bath maintained at $38 \mathrm{C}$. Nitrogen gas was bubbled via the inlet tube into the soil suspension at a flow rate of $700 \mathrm{ml} / \mathrm{min}$ for $10 \mathrm{~min}$. The exhaust gas from the outlet tube was successively passed through traps 1 and 2 which consist of a $4 \mathrm{~mm}$ i.d. $\times 60 \mathrm{~cm}$ U-shaped Teflon tube. The latter was packed with $500 \mathrm{mg}$ of Flusin T (30-60 mesh) as adsorbent. Trap 1 was maintained at $-20 \mathrm{C}$ to remove the moisture. Trap 2 was immersed in an ethanol bath at a temperature ranging from $-20 \mathrm{C}$ to $-60 \mathrm{C}$.

Analysis of volatile substances. Qualitative and quantitative determinations of hydrogen sulfide $\left(\mathrm{H}_{2} \mathrm{~S}\right)$, carbonyl sulfide $(\mathrm{COS})$, phosphine, ethylene and ethylene oxide in the soil flooded with a glucose solution were carried out by using the combined cryogenic collection-gas chromatographic system described by Farwell et al. ${ }^{6)}$ with a slight modification. The gas chromatograph used was a Hitachi model 163 instrument equipp- 
ed with a flame photometric detector (FPD) and a flame ionization detector (FID). The columns and their temperatures were as follows: a Teflon tube $(3 \mathrm{~mm}$ i. d. $\times 2 \mathrm{~m})$ packed with chromosorb 101 (80-100 mesh) at $80 \mathrm{C}$ for the detection of sulfur compounds and phosphine, and a glass column $(3 \mathrm{~mm}$ i. $\mathrm{d} . \times 1 \mathrm{~m})$ packed with Porapak $\mathrm{Q}(50-80$ mesh) at $40 \mathrm{C}$ for the determination of ethylene and ethylene oxide. The flow rate of the carrier gas $(\mathrm{He})$ was $50 \mathrm{ml} / \mathrm{min}$.

Quantitative determination of acetic acid and $n$-butyric acid in the soil solution was performed by using a gas chromatograph equipped with FID. A portion (1-5 $\mu \mathrm{l})$ of the soil soultions, whose $\mathrm{pH}$ was adjusted to 2 , was directly injected onto a gas chromatographic column. Operating conditions were as follows: column; glass column ( $3 \mathrm{~mm}$ i.d. $\times 1 \mathrm{~m}$ ) packed with Chromosorb 105 (60-80 mesh), column temperature; $180 \mathrm{C}$, flow rate of carrier gas $(\mathrm{He}) 50 \mathrm{ml} / \mathrm{min}$.

Mass spectra of the volatile substances collected cryogenically were obtained with a JEOL JMS-D 300 gas chromatograph-mass spectrometer (GC-MS) at $70 \mathrm{eV}$. Gas chromatographic separation was carried out using a glass column $(2 \mathrm{~mm}$ i. d. $\times 1.2 \mathrm{~m})$ packed with Chromosorb $105(60-80 \mathrm{mesh})$ at $180 \mathrm{C}$. The flow rate of the carrier gas $(\mathrm{He})$ was $30 \mathrm{ml} / \mathrm{min}$.

Formic acid and lactic acid concentrations in the soil solutions were determined by a high performance liquid chromatograph equipped with a Shodex Ionpak S-811 column and a UV absorbance detector $(210 \mathrm{~nm})$. The acids were eluted with $0.01 \mathrm{~N} \mathrm{H}_{2} \mathrm{SO}_{4}$ at a flow rate of $1.0 \mathrm{ml} / \mathrm{min}$.

Bioassay. Chlamydospores of $F$. oxysporum were obtained by the method described previously ${ }^{14)}$. In the germination test, the spore suspension was diluted to $1 \times 10^{4}$ spores $/ \mathrm{ml}$ with the supernatant fraction (BMS) of a mineral salt solution ${ }^{14)}$ and with BMS amended with glucose at $100 \mathrm{mM}$ (BMSG). The suspension was diluted with sterile water for the fungicidal test.

Effect of $\mathrm{H}_{2} \mathrm{~S}$ on chlamydospore germination was assayed as follows. Chlamydospore suspension was mounted on a microscopic glass-slide coated with a collodion film in three places. Two sheets of the slide were placed in the head-space of a $9,000 \mathrm{ml}$ closed chamber containing $2,000 \mathrm{ml}$ of $\mathrm{H}_{2} \mathrm{~S}$ aqueous solutions. The initial concentrations of these solutions were $0.2,0.48$ and $0.93 \mathrm{ppm}$, respectively. The concentration was determined by applying the methylene blue method ${ }^{8}$.

Activity of the volatile substances collected by the cryogenic-trap was assayed by the germination test. The adsorbent in the trap was transferred into a small Petri dish $(4.0 \mathrm{~cm}$ i.d. $\times 15 \mathrm{~cm}$ height) and the chlamydospore suspension mounted on a microscopic cover-glass coated with a collodion film was placed in the head-space of the petri dish. The top of the Petri dish was exchanged with the bottom of another Petri dish and was sealed with a Teflon tape.

Inhibitory activity of acetic acid and n-butyric acid on chlamydospore germination was tested by exposing the chlamydospore suspension mounted on microscopic glassslides to the head-space gas above $20 \mathrm{ml}$ of aqueous solutions of acetic acid or n-butyric acid placed in a $15-\mathrm{cm}$ Petri dish. Germination was examined after $15 \mathrm{hr}$ of incubation at $28 \mathrm{C}$ in all the experiments. 
Fungicidal activity of the soil flooded with the glucose solution was assayed as follows. An aliquot $(1.0 \mathrm{ml})$ of the chlamydospore suspension $\left(5 \times 10^{6}\right.$ spores $\left./ \mathrm{ml}\right)$ was seeded to each of the flooded soils amended with and without glucose in 200-ml Erlenmyer flasks. After $24 \mathrm{hr}$ of incubation at $28 \mathrm{C}$, the number of fungi was counted by the dilution plate method described previously ${ }^{15}$. The fungicidal activity was expressed as the percentage of non-colonizing spores in the treated soil to the colonizing spores in the control soil.

Fungicidal activity of $\mathrm{H}_{2} \mathrm{~S}, \mathrm{COS}$, formic acid, acetic acid and n-butyric acid was assayed as follows. Aqueous solutions of these substances were prepared to reach twice the final concentration, and each $10 \mathrm{ml}$ of the solutions was put in a 100-ml Erlenmyer flask containing $1 \mathrm{ml}$ of spore suspension and $9 \mathrm{ml}$ of distilled water. The flasks were plugged tightly with a rubber stopper covered with a polyethylene film. The solution was substituted for $10 \mathrm{ml}$ of distilled water for the control. Microconidia of F. oxysporum were used as an inoculum $\left(1 \times 10^{5}\right.$ spores $\left./ \mathrm{ml}\right)$ in assays of $\mathrm{H}_{2} \mathrm{~S}$ and COS, and the number of colonizing and non-colonizing spores was counted by the dilution plate method after 3 days of incubation at $28 \mathrm{C}$. Chlamydospores of $F$. oxysporum $\left(1 \times 10^{6}\right.$ spores $/ \mathrm{ml}$ ) were used in assays of formic acid, acetic acid and n-butyric acid, and the colonizing spores were counted after 1 day of incubation at $28 \mathrm{C}$.

\section{Results}

\section{Time-course of fungicidal activity in the soil flooded with a glucose solution}

Fig. 2 shows the changes in the fungicidal activity of the soil flooded with the glucose solution. The activity appeared during the first 3 days after flooding and reached the maximum values on the 6 th day. About $90 \%$ of the chlamydospores were killed in the soil at that time after incubation for $24 \mathrm{hr}$. Evidently, glucose-amendment induces fungicidal capacity in the soil, reconfirming the findings reported in the previous paper $^{15)}$. About $15 \%$ of the chlamydospores were killed in the soil even on the 14 th day.

Determination of hydrogen sulfide and carbonyl sulfide concentrations in the soil flooded with a glucose solution and their effect of F. oxysporum

Hydrogen sulfide and COS concentrations were measured to determine whether these substances were associated with the the fungicidal activity of the soil flooded with the glucose solution. The soil solution contained $1.3-2.4 \times 10^{-3} \mathrm{ppm}$ of $\mathrm{H}_{2} \mathrm{~S}$ on the 6 th day, and $0.03 \times 10^{-3} \mathrm{ppm}$ of $\mathrm{COS}$ on the 7 th day. Other sulfur compounds were hardly detected among the active volatile substances collected from the soil flooded with the glucose solution by the cryogenic trap 2 cooled at $-35 \mathrm{C}$, as described later. Chlamydospore germination reached 64 and $0.5 \%$ in the head-space gas above the $\mathrm{H}_{2} \mathrm{~S}$ solutions at the concentrations of 0.2 and $0.48 \mathrm{ppm}$, respectively, when BMS was used as the medium, and germination was about $90 \%$ in the case of BMSG. About $90 \%$ of the microconidia were killed in $0.4 \mathrm{ppm}$ of $\mathrm{H}_{2} \mathrm{~S}$ solution during the 3 day incubation period. None of the spores were killed at a concentration of $0.18 \mathrm{ppm}$. No effect was observed when the microconidia were placed in $2 \times 10^{-3} \mathrm{ppm}$ of $\operatorname{COS}$ solution during 3 days. These results indicate that the volatile sulfur compounds are not associated with the fungicidal activity of the soil. Beside the volatile sulfur compounds, phosphine, ethylene 


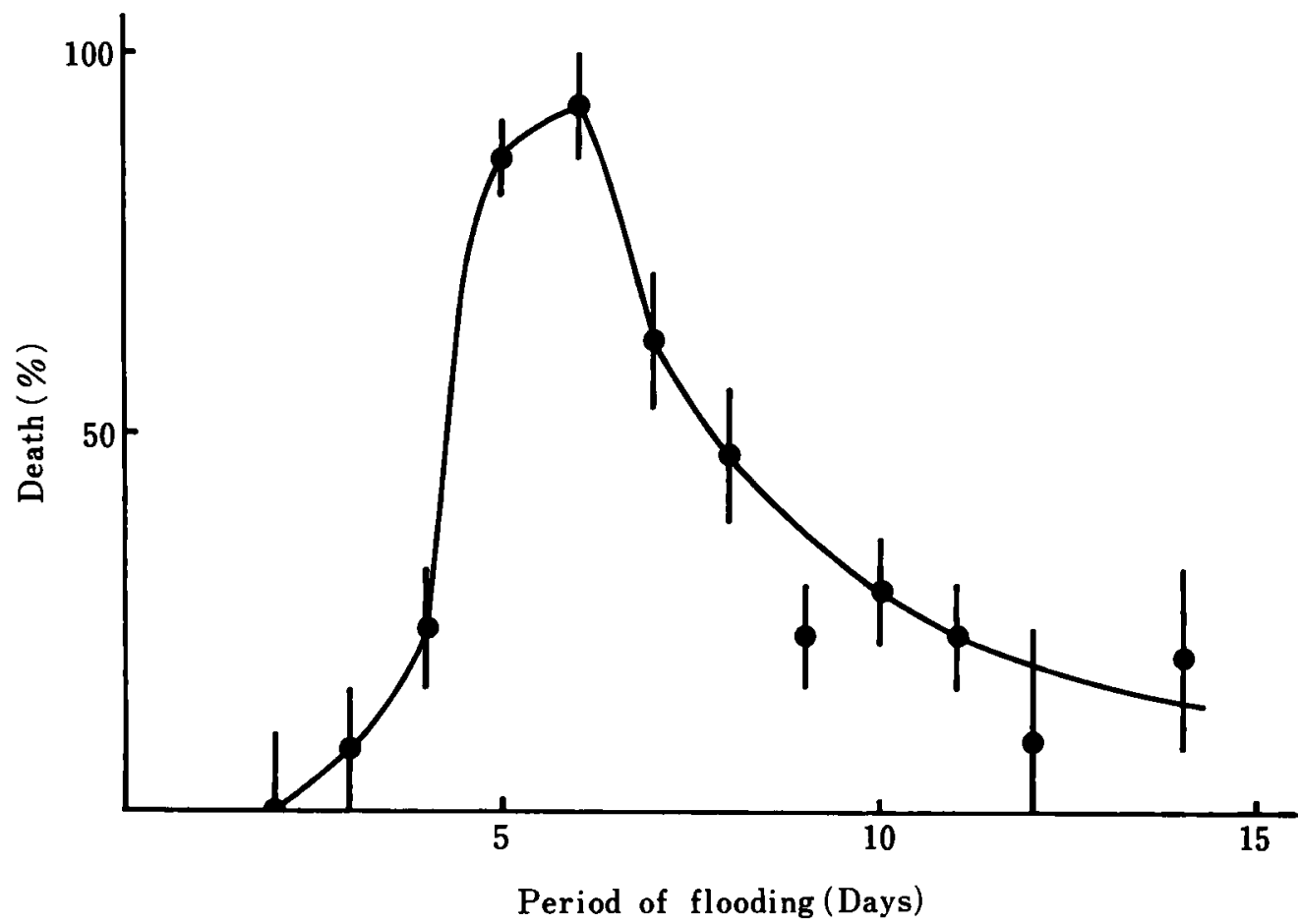

Fig. 2. Time-course of fungicidal activity in glucose-amended flooded soil. The activity was represented as the rate of the death of chlamydospores of $F$. oxysporum in the soil after $24 \mathrm{hr}$ of incubation at $28 \mathrm{C}$. The rate was calculated by the following equation: $\left(1-\frac{\text { number of survivors in glucose-amended flooded soil }}{\text { number of survivors in unamended flooded soil }}\right) \times 100$ Vertical line at each point represents $95 \%$ confidence limit.

and ethylene oxide were also analyzed, but they could not be detected.

Isolation and identification of volatile fungicidal substances from the soil flooded with a glucose solution

The volatile substances inhibiting chlamydospore germination were caught by the cryogenic trap when the trap temperature was kept below $-35 \mathrm{C}$. However, the substances remained in the soil at pH 5.5 or above during the expulsion as shown in Table 1. This observation suggests that the substances are acids. The active components were collected from the soil at $\mathrm{pH} 3.4$ after removal of the inactive volatile substances by bubbling $\mathrm{N}_{2}$ gas into the soil at $\mathrm{pH} 5.5$, and then subjected to GC and GC-MS analysis. Three peaks with Rt. 0.7, 2.4 and 12.0 were observed on the gas chromatogram. Comparing the Rt. on the gas chromatogram and the mass spectra of authentic substances, the peaks with Rt. 2.4 and 12.0 were identified as acetic acid and n-butyric acid, respectively (data not shown). The Rt. of 0.7 coincided with the Rt. of authentic ethanol. These results suggest that acetic acid and n-butyric acid are the main components of active volatile materials in the soil flooded with a glucose solution.

Determination of acetic acid and n-butyric acid concentrations in the soil flooded with a glucose solution and the effect of these substances on $F$. oxysporum 
Table 1. Effect of soil $\mathrm{pH}$ on volatility of antifungal substances in glucose-amended flooded soil

\begin{tabular}{l|c|c}
\hline \multicolumn{1}{c|}{ Treatmenta) } & Germination (\%) \\
\hline No treatment & pH of soil & 0 \\
$2 \mathrm{~N} \mathrm{HCl}(1.0 \mathrm{ml})$ & 2.4 & 0 \\
$2 \mathrm{~N} \mathrm{NaOH}(1.0 \mathrm{ml})$ & 9.7 & 88 \\
$1 \mathrm{~N} \mathrm{NaHCO}(1.0 \mathrm{ml})$ & 5.5 & 89 \\
$1 \mathrm{~N} \mathrm{NaHCO}$ & 0 \\
\hline
\end{tabular}

a) Volatile substances were collected from glucose-amended flooded soil after addition of $2 \mathrm{~N} \mathrm{HCl}, 2 \mathrm{~N} \mathrm{NaOH}$ or $1 \mathrm{~N} \mathrm{NaHCO}_{3}$. Figures in parenthesis indicate the amount of the acid or bases added to the soil. Percentage germination of the spores was $89 \%$ in a control. The medium used was BMSG.

b) Nitrogen gas was bubbled through the soil to which $1.0 \mathrm{ml}$ of $\mathrm{N} \mathrm{NaHCO}_{3}$ had been added and then the volatile substances were collected after addition of $1.0 \mathrm{ml}$ of $2 \mathrm{~N} \mathrm{HCl}$.

Table 2. Concentrations of acetic acid and n-butyric acid in the centrifugedsupernatants from the soils flooded with and without glucose

\begin{tabular}{c|c|c|c}
\hline \multirow{2}{*}{ Flooded period (days) } & Soil condition & \multicolumn{2}{|c}{ Concentration(ppm) } \\
\cline { 2 - 4 } & Flooded & Acetic acid & n-Butyric acid \\
\hline \multirow{3}{*}{3} & Flooded +Glucose & $534 \pm 74$ & N. D. a) \\
& Flooded & $80 \pm 20$ & $564 \pm 49$ \\
6 & Flooded +Glucose & $3407 \pm 171$ & N. D. \\
& Flooded & N. D. & $2944 \pm 259$ \\
12 & Flooded +Glucose & $428 \pm 162$ & N. D. \\
\hline
\end{tabular}

a) Not detected (less than $30 \mathrm{ppm}$ ).

To determine whether acetic acid and n-butyric acid play a role in the fungicidal activity of the soil flooded with a glucose solution, their concentrations in the soil and fungicidal activity were determined. Table 2 shows the concentrations of acetic acid and n-butyric acid in the soil solutions from the soils incubated for 3,6 and 12 days after flooding with and without glucose. Acetic acid and n-butyric acid were present at the concentrations of 3,407 and $2,944 \mathrm{ppm}$, respectively, in the soil solution on the 6 th day, when the fungicidal activity reached maximum values. In contrast to the soil flooded with a glucose solution, no significant amounts of acetic acid and n-butyric acid were detected in the absence of glucose. As shown in Table 3, n-butyric acid almost completely inhibited chlamydospore germination at a concentration of $500 \mathrm{ppm}$, and acetic acid at 3,000 ppm. The inhibitory activity of the acids slightly decreased in a medium with glucose. Fig. 3 shows the concentration-response curves of acetic acid, nbutyric acid and a mixture containing equal amounts of these substances for killing the chlamydospores. Each of them almost completely killed chlamydospores at a concentration of $3,000 \mathrm{ppm}$ or higher during the $24 \mathrm{hr}$ period of incubation. Concentrations of acetic acid and n-butyric acid lethal for $50 \%$ of the spores (LC 50) were 1,506 and $1,522 \mathrm{ppm}$, respectively. LC 50 value of the mixed-solution was $1,252 \mathrm{ppm}$. These re- 
Table 3. Inhibitory activity of acetic acid and n-butyric acid on germination of chlamydospores of $F$. oxysporum f. sp. raphania)

\begin{tabular}{|c|c|c|c|}
\hline \multirow{2}{*}{ Concentration (ppm) } & \multirow{2}{*}{ Mediumb) } & \multicolumn{2}{|c|}{ Germination $(\%)$} \\
\hline & & Acetic acid & n-Butyric acid \\
\hline \multirow{2}{*}{0} & BMS & $93.8 \pm 0.6$ & $93.8 \pm 0.6$ \\
\hline & BMSG & $94.3 \pm 0.8$ & $94.3 \pm 0.8$ \\
\hline \multirow{2}{*}{50} & BMS & $94.0 \pm 0.7$ & $94.6 \pm 1.0$ \\
\hline & BMRG & $95.9 \pm 1.1$ & $97.8 \pm 0.5$ \\
\hline \multirow{2}{*}{100} & BMS & $95.7 \pm 0.6$ & $90.3 \pm 1.4$ \\
\hline & BMSG & $95.5 \pm 1.4$ & $97.2 \pm 0.5$ \\
\hline \multirow{2}{*}{250} & BMS & $90.9 \pm 0.7$ & $70.6 \pm 3.2$ \\
\hline & BMSG & $94.5 \pm 0.6$ & $97.1 \pm 0.7$ \\
\hline \multirow{2}{*}{500} & BMS & $87.7 \pm 2.6$ & $1.1 \pm 0.4$ \\
\hline & BMSG & $96.5 \pm 0.4$ & $4.6 \pm 1.9$ \\
\hline \multirow{2}{*}{1,000} & BMS & $65.4 \pm 1.5$ & 0 \\
\hline & BMSG & $96.2 \pm 1.0$ & $0.2 \pm 0.2$ \\
\hline \multirow{2}{*}{2,000} & BMS & $15.7 \pm 2.4$ & - \\
\hline & BMSG & $71.7 \pm 4.7$ & - \\
\hline \multirow{2}{*}{3,000} & BMS & 0 & - \\
\hline & BMSG & $0.7 \pm 0.4$ & - \\
\hline
\end{tabular}

a) The germination test was conducted by exposing chlamydospore suspensions to the head-space gas abovo $20 \mathrm{ml}$ of aqueous solutions of acetic acid or n-butyric acid placed in a $15-\mathrm{cm}$ petri dish.

b) BMS: supernatant fraction of a mineral salt solution.

BMSG: BMS+glucose.

sults indicate that the levels of acetic acid and n-butyric acid exceeded the lethal concentration for chlamydospores in the soil on the 6th day. In a separate experiment, formic acid concentration was below $30 \mathrm{ppm}$ in the soil solution on the 6th day and formic acid did not kill the chlamydospores at a concentration of below $50 \mathrm{ppm}$. Lactic acid was not detected.

\section{Discussion}

Hydrogen sulfide which is one of the sulfur compounds commonly formed in flooded soils ${ }^{20)}$ is toxic to animals ${ }^{25)}$, plants ${ }^{11)}$ and microorganisms ${ }^{10)}$. Beside $\mathrm{H}_{2} \mathrm{~S}$, a number of volatile sulfur compounds are formed in flooded soil ${ }^{2,13)}$. In the present studies, however, the concentration of each of $\mathrm{H}_{2} \mathrm{~S}$ and $\mathrm{COS}$ in the soil flooded with a glucose solution was much lower than that required for killing the spores. Other sulfur compounds were hardly detected in the cryogenic-collection from the soil. Furthermore, although it has been reported that phosphate is reduced to phosphine by anaerobic bacteria or during the decomposition of organic materials under waterlogged conditions ${ }^{3)}$, such a compound could not been detected in this study. These compounds were, therefore, not associated with the fungicidal activity of the soil. In contrast to these compounds, significant amounts of acetic acid and n-butyric acid were present as components of antifungal volatile substances from the soil. Their concentrations in the soil solution 

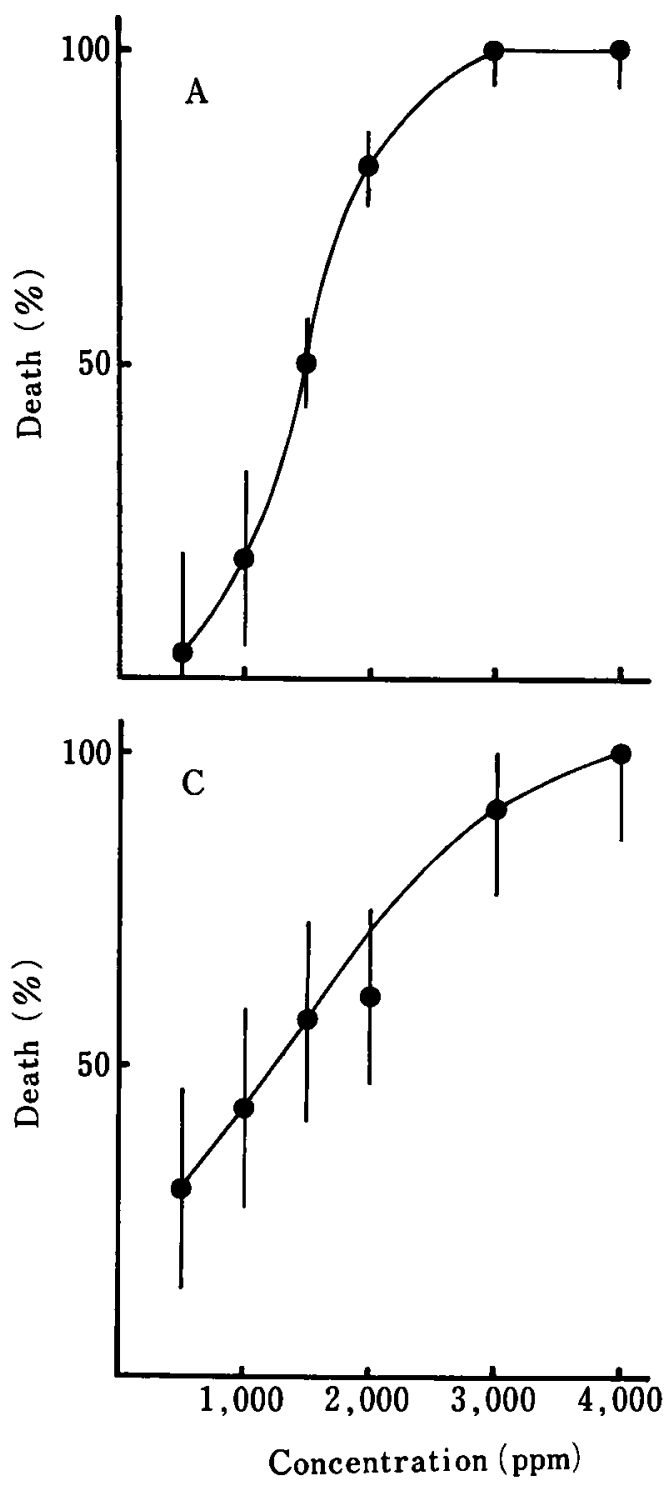

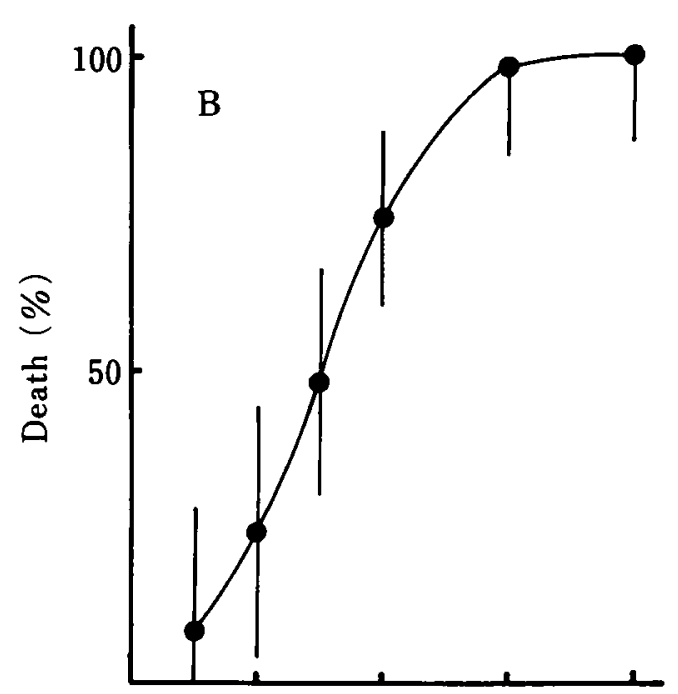

Fig. 3. Concentration-response curves of acetic acid, n-butyric acid and their mixture in relation to the death of chlamydospores of $F$. oxysporum. A: curve for acetic acid, B: curve for n-butyric acid, C: curve for a mixture of equal amounts of these acids. The response represents the rate of death of chlamydospores of $F$. oxysporum in the solutions after $24 \mathrm{hr}$ of incubation at $28 \mathrm{C}$. The rate was calculated by the following equation: $\left(1-\frac{\text { number of survivors in the solutions }}{\text { number of survivors in water }}\right) \times 100$ Vertical line at each point represents $95 \%$ confidence limit.

were high enough to kill the chlamydospores (Table 2, Fig. 3). Changes of the concentration were positively correlated to the fungicidal activity of the soil (Fig. 2. Table 2). These data indicate that both acids play an important role in the fungicidal activity of the soil. Butyric acid has already been shown to be one of the antifungal substances in the soil flooded with a sucrose solution ${ }^{5}$. Acetic acid has also been considered to be one of the causal agents for the inactivation of radish-yellow fusarium in radishresidue fermentation under anaerobic conditions ${ }^{9}$. Production of organic acids in flooded soils amended with and without organic materials has been extensively studied with reference to their harmful effects on the growth of rice plants in paddy fields ${ }^{1,22,232}$. The acids mainly consist of acetic acid and n-butyric acid. It was shown that acetic acid and n-butyric acid are produced at concentrations of $1,100-1,860 \mathrm{ppm}$ and 150-860 
ppm, respectively, when four paddy field soils amended with $0.3-0.4 \%$ of milk vetch powder were incubated under flooded conditions in vitro ${ }^{22)}$. About 1,500 ppm of each of both acids was similarly produced in flooded sand amended with $5 \%$ of rice straw powder in an in vitro experiment ${ }^{7)}$. It is, therefore, probable that a sufficient amount of the acids for killing the fungus would be produced in the soil amended with a large amount of readily decomposable organic materials or in a micro-site of soil around the materials under flooded conditions. Fungicidal value of the soil flooded with a glucose solution, however, was always lower than anticipated by the concentrations of acetic acid and $n$-butyric acid detected in the soil. This discrepancy may be ascribed to the difference of 1-1.5 pH unit between the soil and the solutions of the acids used for measuring the concentration-response curves, since the toxicity of fatty acids increases with the lowering of the $\mathrm{pH}^{4}$. Fungicidal activity of acetic acid and n-butyric acid may also be weakened in the soil solution because it has been shown that the toxicity of fatty acids to roots of rice plants was weakened in a soil solution ${ }^{21}$. Although the activity may be reduced to some extent by the rise of the $\mathrm{pH}$ and the presence of mineral salts, the concentrations of these acids seemed to be high enough to kill the fungus.

In the previous paper ${ }^{15}$ it was shown that chlamydospore germination was strongly inhibited in the head-space gas above the soil flooded with a glucose solution. The spore germination was also strongly inhibited in the head-space gas above the n-butyric acid and acetic acid solutions. In the case of n-butyric acid, the inhibitory concentration was about one-sixth compared to the concentration found in the soil solution on the 6 th day (Table 2, Table 3). This finding indicates that the acid is the causal agent of the inhibition in the head-space gas above the soil. In the previous paper ${ }^{15}$ ) it was also observed that the germination of the chlamydospores was suppressed by one-half in the head-space gas above the unamended flooded soil compared with that of the control water. The soil, however, did not contain both acids at inhibitory levels (Table 2). Smith $^{17)}$ suggested that ethylene may act as a soil fungistatic and its production in flooded soil has been reported ${ }^{24}$. Ethylene was not detected under the current conditions. However, the possibility that other volatile inhibitors are produced in unamended flooded soil can not be ruled out.

In summary, volatile fungicidal substances evolved from the soil flooded with a glucose solution in vitro were found to consist of acetic acid and n-butyric acid, providing a possible clue for the mechanism of fungicidal activity observed in flooded soil amended with readily decomposable organic materials.

\section{Literature cited}

1. Baba, I. (1958). Bull. Nat. Inst. Agr. Sci. Ser. D7 : 1-157.

2. Banwart, W. L. and Bremner, J. M. (1976). Soil Biol. Biochem. $8: 19-22$.

3. Burford, J. R. and Bremner J. M. (1972). Ibid. 4 : 489-495.

4. Cocharane, V. W. (1958). Physiology of Fungi, John Wiley \& Sons Inc., New York. pp. 454-457.

5. Egawa, H., Endo, M. and Ogura, H. In (1983). J. Antibact. Antifung. Agents $11: 563-566$.

6. Farwell, S. O., Gluck, S. J., Bamesberger, W. L., Schutte, T. M. and Adams, D. F. (1979). Anal. Chem. $51: 609-615$.

7. Fujii, K., Kobayashi, T., Haque, M. Z. and Takahashi, E. (1970). J. Sci. Soil Manure Japan 41 : 287-290. 
8. Fukui, S., Naito, S., Kaneko, M. and Kanno, S. (1967). Eisei Kagaku $13: 16-21$.

9. Hagiwara, H., Yano, M., Sakamoto, N. and Takeuchi, S. (1984). Ann. Phytopath. Soc. Japan 50 : 388-389 (Abstr.).

10. McCallan, S.E. A. and Wilcoxon, F. (1931). Contrib. Boyce Thompson Inst. 3:13-38.

11. McCallan, S. E. A., Hartzell, A. and Wilcoxon, F. (1936). Ibid. $8: 189-197$.

12. Menzies, J. D. (1962). Phytopathology $52: 743$ (Abstr.).

13. Minami, K., Okayama, K. and Fukushi, S. (1981). J. Sci. Soil Manure Japan 52:375-380.

14. Okazaki, H. (1975). Ann Phytopath. Soc. Japan $41: 314-320$.

15. Okazaki, H. (1985). Ibid. $51: 264-271$.

16. Okazaki, H. (1985). Ibid. $51: 328$ (Abstr.).

17. Smith, A. M. (1973). Nature $246: 311-313$.

18. Sonku, Y. and Kita, K. (1979). Ann. Phytopath. Soc. Japan $45: 524-525$ (Abstr.).

19. Sonku. Y., Kita, K. and Hidaka, K. (1980). Ibid. $46: 392-393$ (Abstr.).

20. Suzuki, S. and Shiga, H. (1953). Bull. Chugoku Nat. Agr. Exp. Stn. $2:$ 57-72.

21. Takijima, Y. (1961). J. Sci. Soil Manure Japan 32:193-197.

22. Takijima, Y. and Sakuma, H. (1961). Ibid. $32: 559-564$.

.23. Yamane, I. and Sato, K. (1967). Soil Sci. Plant Nutr. $13: 94-100$.

24. Yoshida, T. and Suzuki, M. (1975). Ibid. 21:129-135.

25. Weedon, F. R., Hartzell, A. and Setterstrom, C. (1940). Contrib. Boyce Thompson Inst. $11: 365-$ 385 .

26. Watanabe B. (1973). Ann. Phytopath. Soc. Japan $39: 200$ (Abstr.).

\section{和 文 摘 要}

\section{岡㥓 博・能勢和夫：グルコース添加湛水土壌に発現する殺菌作用の原因物質について}

グルコース添加湛水土埪の殺菌作用は土壤中に産生する揮発性抗菌物質と密接な関係がある。この揮発性抗 菌物質を明ら加にするために畑土㙵 $(10 \mathrm{~g})$ に $3 \%$ グルコース液 $(10 \mathrm{ml})$ を加えて保温静置した土境の揮発性 成分の分析および検出された成分の Fusarium oxysporum f. sp. raphani に対する抗菌性の検定を行った。揮 発性成分の分析は土㙵の殺菌力が最高になる湛水後 6 日目の土壌について行った。硫化水素，硫化カルボニル を含めて土壤中の揮発性硫黄化合物の濃度はきわめて低く本菌の死滅に関係するとは考えられなかった。エチ レン，エチレンオキシド，ホスフィンは検出されなかった。抗菌性を有する覑発性成分は土壤に窒素ガスを通

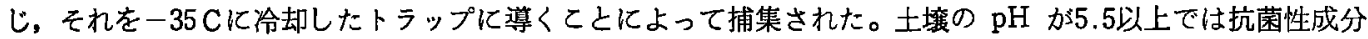
は駆出されず有機酸であるてとが示唆された。トラップで捕集した抗菌性成分をガスクロマトグラフィーおよ びガスクロマトグラフィー一質量分析法によって分析した結果, 捕集成分は酶酸, $\mathrm{n}$-酪酸および微量のエタ, ールであった。このととから抗菌性は酷酸, $\mathrm{n}$-酪酸によるものと推定された。一方, 酢酸および $\mathrm{n}$-酪酸の本 菌厚膜胞子に対する24時間後の LC 50 はそれぞれ 1,506 ppm および 1,522 ppm であった。また，6日目の 土倳溶液中には酢酸および $\mathrm{n}$-酪酸がそれぞれ $3,407 \mathrm{ppm}$ および $2,944 \mathrm{ppm}$ 存在し, それは厚膜胞子を死隇

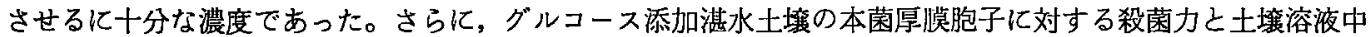
の酢酸および n-酪酸の濃度との間には正の相関が認められた。以上の結果加らグルコース添加湛水土㵝にお ける Fusarium oxysporum f. sp. raphani の死隇は土裹中に産生する䣫酸および n-酪酸によるむのであると 結諭した。 